\title{
Challenges and Sustainability Practices of Frontier Schools in Montana
}

\author{
Claudette Morton \\ Montana Small Schools Alliance
}

\author{
Hobart L. Harmon \\ Independent Consultant
}

\begin{abstract}
This article reports the findings of a study commissioned by the Montana Small Schools Alliance to explore the challenges and sustainability practices of frontier schools. A Montana frontier school is defined as a school district with 200 or fewer students with its attendant community located in a county with five or fewer people per square mile. The researchers surveyed teachers, administrators, and school board chairs in 141 frontier school districts and held six focus groups of community members. The top five most important challenges noted by school district personnel were low student enrollment, inadequate financial resources, unrealistic federal expectations, academically unmotivated students, and mixed grade levels of students in the classroom. School sustainability practices included operating mixed-age or multi-grade classrooms and using school facilities to serve critical community functions. Lay citizens, compared to persons employed by the school district, were more likely to view the school as necessary for maintaining a way of life associated with agriculture and related enterprises. Twelve research questions are offered for future research on issues of frontier schools.
\end{abstract}

Keywords: Montana schools; rural schools; rural education; school districts; boards of education; teaching conditions; sustainability.

Educational leaders facing declining student populations and dwindling budgets are once again struggling with the issue of how to sustain small schools in rural communities (Powers, 2009; Ross, 2011). With financial support of The Oro Y Plata Foundation, the Montana Small Schools Alliance (MSSA) established the Frontier Schools Project to increase understanding about, and to provide assistance to, the small rural schools and their communities in the most remote places of the state. As an essential first step the MSSA sought to understand the challenges and sustainability practices of this important element of public education in Montana. The rationale was that profiling the unique challenges facing these small "frontier" schools could enable MSSA and other organizations, as well as state and federal agencies, to develop possible solutions to the challenges and provide supportive assistance.

A further consideration was that revealing facts about frontier schools and their communities in Montana may also begin to inform urban-minded myths and fill an important void in the education literature about the circumstances of such schools that serve a necessary role in rural America. This article reports the findings of surveys and focus group research to identify the challenges and sustainability practices of Montana frontier school districts.

\section{Challenges Rural Schools Face}

The challenges facing rural schools impact all states across the country. For example, Allen and Sloan (2005) reported funding small schools is becoming a pressing issue in Maine because of numerous factors, including state and federal accountability laws and declining enrollments. Challenges facing Maine's small rural schools include attracting and retaining qualified teachers, including specialty teachers such as music teachers, nurses, and science teachers; increasing proportions of students living in poverty, and declining availability of trained special education staff for students with severe, low-incidence disabilities.

Declining student populations, combined with instances of lower test scores and problems with teacher retention, have caused Midwestern states to revisit the question of whether further school consolidations - either through mandates or incentives - need to be considered as part of the solution to providing quality education for students in the 21 st century (Kliewer, 2001). In California, the 
economic crisis threatens the sustainability of small rural schools, particularly the one-room schoolhouses (The Associated Press, 2009). Minnesota researchers (Williams, Nierengarten, Munson, Riordan, \& Corbett, 2009) noted proposed solutions to address economic issues in rural districts have included mandates to consolidate, collaborate and cooperate. Howley, Johnson, and Petrie (2011) pointed out, however, that the extent of consolidation varies across states due to their considerable differences in history, geography, population density, and politics. These authors emphasize "contemporary research does not support claims about the widespread benefits of consolidation. The assumptions behind such claims are most often dangerous oversimplifications" (p. 3).

Numerous researchers and authors have investigated and/or described the challenges rural schools face (Alliance for Excellent Education, 2010; Broton, Mueller, Schultz, \& Gaona, 2009; Brown \& Swanson, 2003; Harmon, 2003; Stephens, 1998) and the close relationship between a rural school and its community (Beaulieu \& Gibbs, 2005; Chance \& Cummins 1988; Gjelten, 1982; Harmon \& Schafft, 2009; Lyson, 2002; Miller, 1993; Scafft \& Harmon, 2010). But little is known about the smallest of the small rural schools, the "frontier schools" serving the most isolated of rural communities across the United States.

\section{Frontier Schools}

Approximately 10 years ago, Howley and Harmon (2000a) reported that more than 1,000 school districts with 200 or fewer students remained in rural areas of the United States. Generally, compared to other locales, a larger percentage of students in rural America are enrolled in very small public schools (Provasnik et al., 2007). At the elementary level, the percentage of students in rural areas attending public schools with an enrollment below $200(10.4 \%)$ was about three times as large as the percentage in towns $(3.4 \%)$, about 7 times as large as the percentage in cities $(1.5 \%)$, and about 10 times as large as the percentage in suburbs $(1 \%)$. At the secondary level, similar differences existed, with the percentage of students in rural areas attending public schools with enrollments of less than 200 (9\%) more than three times larger than the percentages in cities, suburbs, and towns (ranging from 1 to $2 \%$ ).

Educational historians might view small rural schools as remnants of the "one-room" or "country" school (Gaither, 2003; Fuller, 1982). Researchers might view them as outliers or anomalies that seldom fit "normal" schools today (DeYoung, 1991; DeYoung 1987). Yet, these schools possess many of the characteristics that current education reformers seek to implement, such as a smaller and more personalized learning environment for each student, better connections between the school and parents of students, and a focused curriculum that integrates academic and practical learning.

\section{Defining Frontier Schools}

A workable definition of rural schools on the "frontier" has been elusive for educators and researchers. However, when the federal government added the Small, Rural School Achievement Program to the Elementary and Secondary Education Act, it created a definition for allocating funds to small rural school districts. Eligible for funds were school districts of 600 or fewer students in a county with a population density of fewer than 10 persons per square mile and a U.S. Department of Education rural local code of 7 or 8 (US Department of Education, 2002). In the western part of the United States, however, such a definition of rural may be too inclusive. In Montana, for example, the definition included the majority of school districts in the state (McCulloch, 2008). Determining a more accurate operational definition proved to be the first challenge in researching schools on the Montana frontier. MSSA project investigators decided on the term "frontier" to identify the small schools and communities that are actually a sub-group of rural America. Frontier schools exist in places that are exceptionally remote, particularly in comparison to most rural schools in the eastern United States.

Although a review of literature in the Education Resources Information Center (ERIC) system contained considerable information on one-room schools, no documents discussed the modern frontier school. An Internet search revealed that The National Center for Frontier Communities (NCFC) based in Ojo Sarco, New Mexico claims it is "the only national organization dedicated to the smallest and most geographically isolated communities in the United States - the Frontier" (para \#1, home page).

In 1997, NCFC used a methodology from the National Institutes of Health and convened a group of rural health professionals to read background papers and develop a scale of "frontierness" rather than a specific definition. The group weighed three factors. The first was density or persons per square mile; the second was distance to a market or service center, and the third was the time it took to drive to the nearest market or service center. While relevant, the matrix was not satisfactory for the Montana frontier schools project because of the sliding scale features. Consequently, the researchers considered various Montana features of frontier and created an 
operational definition for the MSSA project. A Montana frontier school was defined as a school district with 200 or fewer students and its attendant community located in a county with five or fewer people per square mile. The 200 -student maximum defined a much smaller school district than the federal definition of 600 students developed for the Small, Rural School Achievement Program. The determination of remoteness embraced a county with five or fewer persons per square mile. Because the school-aged population in Montana makes up 20\% of the general population (Montana Department of Commerce, 2008), a county with five people per square mile would on average have only one student per square mile.

In Montana, 42 of the 56 counties have fewer than five people per square mile (CEIS-Montana, July 2008). Consequently, this became the defined geographic area for the MSSA Frontier Schools project. A review of 2008 student enrollment data from the Montana Office of Public Instruction (McCulloch, 2008) and the list of school districts in the five Montana Regional Service Areas revealed 141 districts that enrolled 200 or fewer students in the 42 counties.

Although many small schools in remote Montana areas offer a learning environment that larger schools in urban areas find almost impossible to emulate, these isolated schools face many challenges that jeopardize their future success and even their existence. The primary purpose of the study was to describe the challenges confronting small rural "frontier" schools in Montana and the practices that contribute to their sustainability. The study provided an opportunity for those most involved in frontier schools -- teachers, administrators, school board chairs, and community supporters (i.e., lay citizens) to provide their perceptions of challenges and sustainability practices of frontier schools.

\section{Methods}

The study used a mixed-methods approach that included initial surveys and follow-up focus groups. The study was conducted in two phases from February 2009 to April 2010. A total of 141 frontier school districts in 42 Montana counties comprised the target population for the study.

\section{Instrument}

Surveys for school district personnel and school board chairs were developed from a survey of K-12 unit schools in the United States designed by Howley and Harmon (2000a). The survey was pilot tested over a two-month period with four school districts in the fall of 2008 and slight modifications made to clarify selected questions. The survey contained 20 questions, including demographic information, current school district challenges, and practices that may contribute to the sustainability of the school. School and district personnel were asked to indicate (a) what they perceived were the major challenges to the district, and (b) to explain the first, second and third most important challenges. A challenge was defined as a pressing issue at the current time. School board chairs were asked to indicate in order of importance the three greatest challenges facing the school district at the current time. Using a rating scale of not important, somewhat important, important, very important, and extremely important, school district personnel and school board chairs were asked to rate the importance of eight factors in sustaining small rural public school(s) in the school district.

\section{Procedures}

In phase one, the Montana Small Schools Alliance office administered the survey to frontier school district personnel who participated in MSSA professional development workshop sessions in February and March, 2009. In phase two in January 2010, using Survey Monkey the same instrument was posted on the MSSA web site to solicit responses from personnel (i.e., teachers and administrators) in the frontier school districts who had not participated in the workshops. A similar paper and pencil survey was also developed for completion by school board chairs of each frontier school district. The MSSA office mailed the survey in January 2010, with a timeline of one month to respond, to the 141 school board chairs in the target group.

As a follow-up effort to solicit additional surveys from non-respondents to the web and mailed surveys, county superintendents and regional service center directors were asked to disseminate information about the study and to encourage response. A total of 237 school district personnel (92 MSSA workshop participants and 145 web survey participants) completed the surveys. Ensuring confidentiality for teachers and others in small schools was a prime concern for the researchers. Web-participants were requested to provide their school district's four digit legal identity code as an identifier. As most respondents were unable to provide this code, it was impossible to calculate a response rate for the survey population of teachers and administrators; however, it was estimated at between $40-60 \%$ of the target population. The chairs of 57 school boards (40\%) completed the paper and pencil survey. 


\section{Focus Group Participants}

Additionally, workshop, web, and school board chair survey respondents were asked to provide the names and phone numbers of two community members (i.e., lay citizens) not employed by the school district who were strong advocates of the school and knew its value to the community or area the school served. These persons were defined as "local supporters" of the frontier school in their communities and made up the list of 202 potential focus group members, 60 of whom agreed to participate in a focus group. In phase two, the researchers conducted six focus groups across the state of Montana with 49 of the 60 "local supporters" of the frontier schools. A focus group protocol was developed by the researchers to guide focus group sessions. One researcher facilitated the protocol (consultant) while the second researcher (MSSA director) served as note taker. The focus group sessions were conducted in March and April of 2010 in restaurants at a regional location convenient to invited participants. Sessions were held from $6 \mathrm{pm}$ to 8:30 pm with dinner provided. Focus group sessions were recorded, with written transcriptions produced by an experienced court reporter.

\section{Data Analysis}

Data from surveys were entered into the Statistical Package for the Social Sciences (SPSS 11.5 Windows) for analysis. Demographic characteristics were profiled. First, major challenges of the school districts were analyzed, followed by an analysis of practices that contributed to the sustainability of frontier schools. A Cronbach alpha reliability procedure was conducted on the scale of importance ratings for the eight sustainability reasons in the school district personnel survey $(.816)$ and the school board chair survey (.709).

The researchers analyzed the focus group transcriptions as well as the notes taken by the one researcher at each focus group session. Themes regarding the frontier school as critical to a way of life were identified.

\section{Findings}

Highlights of respondent characteristics, school challenges, and sustainability practices and reasons are presented. A copy of the full report, Frontier Schools in Montana: Challenges and Sustainability Practices: A Research Report, is available from the Montana Small Schools Alliance web site at
http://mtsmallschools.org/pdf/Montana\%20Frontier\% 20Schools.pdf

\section{Respondent Characteristics}

Of the 237 respondents who were employed by school districts, 218 indicated their primary position of responsibility in the school district. Forty-two (19.3\%) of these 218 respondents indicated county superintendent as their primary position of responsibility in the school district. Twenty-seven (12.4\%) respondents indicated District Superintendent/Lead Teacher. Only six (2.8\%) respondents indicated they served as District Superintendent and School Principal, while 98 (45.0\%) respondents indicated District Supervising Teacher. Forty-six (19.7\%) respondents were employed as Teachers, and two $(0.9 \%)$ were employed as Clerks (business managers). In Montana, there are still K-8 districts with a Board of Trustees of three and a District Supervising Teacher, who is a classroom teacher with additional duties that in a larger district would be assigned to a principal. The county superintendent is the superintendent of record for these small K-8 schools with no other administrator.

Of the 237 respondents, 220 indicated the type of school district in which they were employed. One hundred and forty-two respondents $(64.5 \%)$ were employed in K-8 districts; 44 respondents (20\%) were employed in K-12 school districts comprised of only one school in district, and 34 respondents $(15.5 \%)$ were employed in K-12 school districts that had more than one school in the district. Just over $40.5 \%$ of employees had held their current position for more than five years.

Agriculture was the most prevalent type of economic base in more than four-fifths $(85.4 \%)$ of districts, followed by mixed economies, government services, and recreation and tourism. Manufacturing and retirement were indicated least frequently as the prevalent type of economic base in the school district.

\section{District Student Population}

Several questions on the survey asked the participants to describe the school district's student population. Of the 221 respondents, $60(27.1 \%)$ indicated a district enrollment of less than 10 students; over half $(53.3 \%)$ specified district enrolment of 30 or fewer students and more than twothirds $(76.8 \%)$ worked in districts that enrolled 75 or fewer students. Fifty-eight $(29.1 \%)$ respondents indicated that more than $50 \%$ of the students in the district were eligible for the federal free and/or 
reduced lunch program. Forty-eight $(24.1 \%)$ respondents reported no students eligible for free and or reduced lunch. However, it is possible that in many of these small frontier schools the respondent did not know if students were eligible for free and/or reduced lunch because most of the schools do not offer a lunch program. Many frontier schools do not have a kitchen or a lunch facility.

\section{Major District Challenges}

Personnel employed by the school district were asked to indicate what they perceived were the major challenges of the district. A challenge was defined as a pressing issue at the current time (Table 1).

\section{Table 1}

District Challenges Noted by School District Personnel

\begin{tabular}{lcc}
\multicolumn{1}{c}{ Challenge } & No. of & \\
\hline 1. Low student enrollment & Respondents & $\%$ \\
2. Unrealistic federal regulations & 137 & 57.8 \\
3. Inadequate financial resources & 119 & 50.2 \\
4. Mixed grade levels of students in classroom & 116 & 48.9 \\
5. Difficulty recruiting qualified teacher(s) & 78 & 32.9 \\
6. Difficulty retaining teachers & 78 & 32.9 \\
7. Unrealistic state regulations & 76 & 32.1 \\
8. Unmotivated students academically & 66 & 27.8 \\
9. Threats of school consolidation or closure & 65 & 27.4 \\
10. Needs of special education students & 57 & 24.1 \\
11. Inadequate parent involvement & 53 & 22.4 \\
12. Antiquated school facilities & 52 & 21.9 \\
13. Providing teacher professional development opportunities & 45 & 19.0 \\
14. Low student achievement & 38 & 16.0 \\
15. Inadequate community support & 33 & 14.0 \\
16. Inappropriate student behavior & 29 & 12.2 \\
17. Lack of student support services & 27 & 11.4 \\
18. Inadequate distance learning technology (e.g., Internet connectivity) & 25 & 10.5 \\
19. Inadequate curriculum/course offerings & 21 & 8.9 \\
20. Inadequate number of support staff & 22 & 9.3 \\
21. Student use of alcohol & 22 & 9.3 \\
22. Meeting teacher certification requirements & 14 & 5.9 \\
23. Other & 13 & 5.5 \\
24. Student use of illegal drugs & 13 & 5.5 \\
\hline
\end{tabular}

The challenge noted by the highest percentage of respondents was low student enrollment (57.8\%), followed by unrealistic federal regulations $(50.2 \%)$, inadequate financial resources (48.9\%), mixed grade levels of students in classroom (32.9\%), and difficulty recruiting qualified teacher(s) (32.9\%).

The challenges respondents noted least frequently were student use of illegal drugs (2.5\%), meeting teacher certification requirements (5.5\%), student use of alcohol (5.9\%), inadequate distance learning technology (e.g., Internet connectivity) (8.9\%), inadequate curriculum/course offerings $(9.3 \%)$, and, inadequate number of support staff $(9.3 \%)$. 


\section{Most Important District Challenges}

After indicating the major challenges faced by the school district, respondents were asked to specify what they perceived were the "most important, "second most important" and "third most important" challenges in the school district (Table 2).

Table 2

Five Most Important Challenges Identified by School District Respondents

\begin{tabular}{lcc}
\hline \multicolumn{1}{c}{ Major Challenge } & $\begin{array}{c}\text { No. of } \\
\text { Respondents }\end{array}$ & $\%$ \\
\hline Low student enrollment & 60 & 28.3 \\
Inadequate financial resources & 20 & 9.4 \\
Unrealistic federal expectations & 20 & 9.4 \\
Academically unmotivated students & 10 & 4.7 \\
Mixed grade levels of students in the classroom & 9 & 4.2 \\
\hline
\end{tabular}

Respondents were asked to explain their reason for indicating a challenge as the most important. Sixty-five of the respondents who indicated that low student enrollment was the most important challenge provided an explanation. Most statements reflected the issue of how declining or low numbers of students translated into less funding, elimination of staff, and possible school consolidation or closure.

Fifty-seven respondents provided statements to explain why the item, inadequate financial resources, was the most important challenge for the school district. Statements reflected the impact of financial resources on instructional materials, facilities repair, teacher salaries, special education services, teacher recruitment and retention, linkage of student enrollment to state funding, and ability to offer necessary programs for all students.

Nineteen respondents provided statements to explain why, unrealistic federal expectations was the most important challenge for the school district. Statements reflected unrealistic expectations of federal mandates because of small student enrollments, limited time for teachers to complete paperwork, an overemphasis on testing as the sole measure of student performance, inadequate federal funding to support implementing requirements of regulations, and a general preference for local control in school decision making.

Ten respondents provided statements to explain why academically unmotivated students was the most important challenge of the school district. Statements reflected the inability of students to see relevance in what they were learning, student unwillingness to extend enough effort to succeed academically, and/or a general lack of student responsibility and motivation.

Nine respondents provided statements to explain why the item, mixed-grade levels of students in classroom, was the most important challenge for the school district. Generally, statements reflected how the multi-grade classroom situation placed constraints on the teacher's time to work with individual students in specific grades to meet expected learning standards.

School board chairs were asked to indicate their perceptions of the three greatest challenges (most pressing issues) in order of importance that currently existed in the school district (see Table 3). Low student enrollment was noted as the greatest challenge by the highest percentage of respondents $(\mathrm{n}=20,35.1 \%)$, followed by inadequate financial resources $(\mathrm{n}=14,24.6 \%)$, and unrealistic federal regulations $(\mathrm{n}=9,15.8 \%)$. These same three challenges were also identified as the second greatest challenge by $12.7 \%$ of respondents. A slightly lower percentage of board chairs noted unrealistic state regulations $(10.9 \%)$ and threats of school consolidation or closure $(10.5 \%)$ as the second greatest challenge. With regard to the third greatest challenge, board chairs noted most frequently unrealistic federal regulations $(21.6 \%)$ and threats of school consolidation or closure (21.6\%). 
Table 3

Greatest, Second Greatest, and Third Greatest Challenges Noted by Board Chairs

\begin{tabular}{|c|c|c|c|c|c|c|}
\hline \multirow[t]{2}{*}{ District Challenge } & \multicolumn{2}{|c|}{$\begin{array}{l}\text { Greatest } \\
\text { Challenge }\end{array}$} & \multicolumn{2}{|c|}{$\begin{array}{l}\text { Second Greatest } \\
\text { Challenge }\end{array}$} & \multicolumn{2}{|c|}{$\begin{array}{l}\text { Third Greatest } \\
\text { Challenge }\end{array}$} \\
\hline & No. & $\%$ & No. & $\%$ & No. & $\%$ \\
\hline 1. Low student enrollment & 20 & 35.1 & 7 & 12.7 & 2 & 3.9 \\
\hline 2. Inadequate financial resources & 14 & 24.6 & 7 & 12.7 & 1 & 2.0 \\
\hline 3. Unrealistic federal regulations & 9 & 15.8 & 7 & 12.7 & 11 & 21.6 \\
\hline 4. Difficulty recruiting qualified teacher(s) & 4 & 7.0 & 3 & 5.3 & 4 & 7.8 \\
\hline 5. Unrealistic state regulations & 3 & 5.3 & 6 & 10.9 & 7 & 13.7 \\
\hline 6. Threats of school consolidation or Closure & 1 & 1.8 & 6 & 10.5 & 11 & 21.6 \\
\hline 7. Difficulty retaining teachers & 1 & 1.8 & 4 & 7.0 & 2 & 3.9 \\
\hline 8. Antiquated school facilities & 1 & 1.8 & 2 & 3.5 & 1 & 2.0 \\
\hline $\begin{array}{l}\text { 9. Inadequate distance learning technology (e.g., } \\
\text { Internet connectivity) }\end{array}$ & 1 & & 2 & 3.5 & 2 & 3.9 \\
\hline 10. Unmotivated students academically & 1 & 1.8 & 1 & 1.8 & 1 & 2.0 \\
\hline 11. Inadequate parent involvement & 1 & 1.8 & 0 & 0 & 0 & 0 \\
\hline 12. Inadequate curriculum/course offerings & 1 & 1.8 & 0 & 0 & 0 & 0 \\
\hline 13. Needs of special education students & 0 & 0 & 5 & 9.1 & 2 & 3.9 \\
\hline 14. Mixed grade levels of students in Classroom & 0 & 0 & 2 & 3.6 & 1 & 2.0 \\
\hline 15. Low student achievement & 0 & 0 & 1 & 1.8 & 2 & 3.9 \\
\hline $\begin{array}{l}\text { 16. Providing teacher professional development } \\
\text { opportunities }\end{array}$ & 0 & 0 & 1 & 1.8 & 1 & 2.0 \\
\hline 17. Inappropriate student behavior & 0 & 0 & 1 & 1.8 & 0 & 0 \\
\hline 18. Other (please specify) & 0 & 0 & 0 & 0 & 2 & 3.9 \\
\hline 19. Meeting teacher certification Requirements & 0 & 0 & 0 & 0 & 1 & 2.0 \\
\hline 20. Lack of student support services & 0 & 0 & 0 & 0 & 0 & 0 \\
\hline Total & 57 & 100.0 & 55 & 100.0 & 51 & 100.0 \\
\hline
\end{tabular}

\section{Sustainability Practices}

School district personnel were asked to indicate if selected practices contributed to school sustainability in the district. These practices were grouped into four categories: (1) general operations, (2) staffing, (3) fiscal, and (4) distance learning technology. Approximately two-thirds of the respondents $(\mathrm{n}=161,67.9 \%)$ reported the general operations practice of operating multi-grade classrooms contributed to school sustainability in the district. Ninety-nine respondents $(41.8 \%)$ indicated that operating school facilities to serve community functions positively impacted sustainability. Slightly more than one in ten $(\mathrm{n}=28,11.9 \%)$ reported that operating on a 4-day schedule contributed to school sustainability.

The highest percentage of respondents $(\mathrm{n}=107$, 45.1\%) selected Made available special in-service opportunities as a staffing practice that contributed to school sustainability in the district. The second most commonly identified sustainability practice was Created partnerships with other districts $(\mathrm{n}=74$, $31.2 \%)$, followed by Employed teacher(s) with multiple endorsements $(\mathrm{n}=73,30.9 \%)$, Passed local levy $(\mathrm{n}=72,30.4 \%)$, and Promoted reputation of school $(\mathrm{n}=72,30.4 \%)$. Interestingly, only nine respondents selected Recruited teachers more aggressively from selected colleges and only two respondents indicated Offered teacher induction program as a staffing practices that contributed to school sustainability in the district. In small, remote rural schools it is difficult to operate a teacher induction program when the new teacher may be the only professional educator in the school.

The fiscal practices that the highest numbers of respondents perceived contributed to school sustainability in districts were Sought bids and comparison pricing for all purchases $(\mathrm{n}=93,39.2 \%)$, Formed consortium of school districts to leverage 
resources $(\mathrm{n}=93,39.2 \%)$, Cooperated with other districts for specialized personnel $(\mathrm{n}=92,38.8 \%)$, Increased student count (e.g., all-day kindergarten) $(\mathrm{n}=88,37.1 \%)$ and Hired teachers on low end of district pay scale $(\mathrm{n}=87,36.7 \%)$.

With regard to distance learning technology practices that contribute to school sustainability in district, 97 (40.9\%) respondents indicated Delivered professional development opportunities for teachers and 90 respondents $(38.0 \%)$ selected Provided enrichment experiences for students. A much lower percentage of respondents designated the following as important technology practices that contribute to sustainability: Provided citizens access to Internet $(\mathrm{n}=40,16.9 \%)$, Offered courses to meet statemandated curriculum requirements $(\mathrm{n}=39,16.5 \%)$, Offered advanced placement courses for college bound students $(\mathrm{n}=30,12.7 \%)$, Offered school board training ( $\mathrm{n}=30,12.7 \%)$, and Delivered professional development opportunities for administrators $(\mathrm{n}=27$,
$11.4 \%$ ). Because the vast majority of the respondents in the survey worked in elementary school districts, a lower selection of the practices particularly relevant to high schools may be expected.

\section{Sustainability Reasons}

Using a rating scale of not important, somewhat important, important, very important, and extremely important, school district personnel were asked to rate the importance of eight factors in sustaining small rural public school(s) in the school district (Table 4). Based on the combined ratings of very and extremely important, respondents indicated Importance of school to the community in educating children and/or youth almost twice as often (70\%) as any other reason. Lack of opposition in the district to closing the school was selected as the reason by the second highest percentage $(38.8 \%)$ of school district personnel.

\section{Table 4}

Rating of Sustainability Reasons by School District Personnel

\begin{tabular}{|c|c|c|c|c|c|c|}
\hline \multirow[b]{3}{*}{ Sustainability Reason } & \multicolumn{6}{|c|}{ Respondent Ratings $(\mathrm{n}=183)$} \\
\hline & \multicolumn{2}{|c|}{$\begin{array}{c}\text { Very } \\
\text { Important }\end{array}$} & \multicolumn{2}{|c|}{$\begin{array}{l}\text { Extremely } \\
\text { Important }\end{array}$} & \multicolumn{2}{|c|}{ Combined } \\
\hline & No. & $\%$ & No. & $\%$ & No. & $\%$ \\
\hline $\begin{array}{l}\text { 1. Importance of school to the community in } \\
\text { educating children and/or youth }(n=190)\end{array}$ & 91 & 47.9 & 42 & 22.1 & 133 & 70.0 \\
\hline $\begin{array}{l}\text { 2. Lack of opposition in the district to closing the } \\
\text { school }(n=180)\end{array}$ & 51 & 28.2 & 19 & 10.6 & 70 & 38.8 \\
\hline $\begin{array}{l}\text { 3. Geography and road conditions are safer to travel } \\
\text { in winter than nearest out-of-district school }(n=190)\end{array}$ & 50 & 26.3 & 17 & 8.9 & 67 & 35.2 \\
\hline $\begin{array}{l}\text { 4. Lack of external pressure (outside of district) to } \\
\text { close the school }(n=180)\end{array}$ & 45 & 25.0 & 16 & 8.9 & 61 & 33.9 \\
\hline $\begin{array}{l}\text { 5. Travel distance is too far for students to attend } \\
\text { nearest out-of-district school }(n=189)\end{array}$ & 49 & 25.9 & 14 & 7.4 & 63 & 33.3 \\
\hline $\begin{array}{l}\text { 6. Importance of school to the community in } \\
\text { meeting community development functions or needs } \\
(n=190)\end{array}$ & 43 & 22.6 & 15 & 7.9 & 58 & 31.6 \\
\hline $\begin{array}{l}\text { 7. Key politicians representing the rural area } \\
\text { strongly support the school }(n=182)\end{array}$ & 39 & 21.4 & 11 & 6.0 & 50 & 27.4 \\
\hline $\begin{array}{l}\text { 8. School operating expenditures basically same as } \\
\text { schools in other neighboring districts }\end{array}$ & 35 & 19.1 & 3 & 1.6 & 38 & 20.7 \\
\hline
\end{tabular}

School board chairs also rated the importance of the eight reasons in sustaining the small rural public school(s) in the district (Table 5). Similar to school district personnel, the factor school board chairs rated most highly was Importance of school to the community in educating children and/or youth. In contrast to district personnel, however, school board chairs generally rated the sustainability impact of more factors as very or extremely important. In essence, personnel who work for the school district (e.g., teachers, administrators, others) perceive some sustainability factors as much less important than do school board chairs. For example, $73.7 \%$ of school board chairs indicated as extremely important the factor Importance of school to the community in educating children and/or youth, compared to $22.1 \%$ of school district personnel respondents. Given the political nature of the school board, it is not 
surprising that $41.5 \%$ of school board chairs indicated as extremely important the sustainability impact of the factor Key politicians representing the rural area strongly support the school, compared to only $6 \%$ of the school district personnel.

\section{Table 5}

Rating of Sustainability Reasons by School Board Chairs

\section{Sustainability Reason}

1. Importance of school to the community in educating children and/or youth $(\mathrm{n}=57)$

2. Key politicians representing the rural area strongly support the school $(\mathrm{n}=53)$

3. Geography and road conditions are safer to travel in winter than nearest out-of-district school $(n=57)$

4. Importance of school to the community in meeting community development functions or needs $(n=57)$

5. Travel distance is too far for students to attend nearest out-ofdistrict school $(n=57)$

6. Lack of opposition in the district to closing the school $(n=52)$

7. Lack of external pressure (outside of district) to close the school $(n=53)$

8. School operating expenditures basically same as schools in other neighboring districts $(\mathrm{n}=56)$

\begin{tabular}{cccccc}
\multicolumn{6}{c}{ Respondent Ratings } \\
\hline \multicolumn{2}{c}{ Very } & \multicolumn{2}{c}{ Extremely } & \multicolumn{2}{c}{ Combined } \\
Important & Important & & \\
\hline No. & $\%$ & No. & $\%$ & No. & $\%$ \\
\hline 11 & 19.3 & 42 & 73.7 & 53 & 93.0 \\
& & & & & \\
9 & 17.0 & 22 & 41.5 & 31 & 58.5 \\
18 & 31.7 & 15 & 26.3 & 33 & 58.0 \\
& & & & & \\
19 & 33.4 & 10 & 17.5 & 29 & 50.9 \\
12 & 21.1 & 17 & 29.8 & 29 & 50.9 \\
6 & 11.5 & 20 & 38.5 & 26 & 50.0 \\
6 & 11.3 & 15 & 28.3 & 21 & 39.6 \\
16 & 28.6 & 4 & 7.1 & 20 & 35.7 \\
& & & & & \\
\hline
\end{tabular}

\section{Frontier School Supporters}

Forty-nine individuals suggested by school district personnel and board chairs as strong supporters of the frontier community school participated in the six focus group sessions. The 35 cars or trucks that brought the 49 participants to these sessions traveled 3,282 miles, a round trip on average of 96.8 miles. Reflecting the long distances that residents may need to travel to attend meetings in some rural areas of Montana served by frontier schools, one husband and wife traveled a 240 mile round trip to attend the session in their area.

Session participants were asked to describe characteristics of their school, how parents and community (or area) valued the school, the greatest challenge facing the school over the next three years, and to recommend possible solutions to the challenge. Session participants were also asked to explain why the school had been sustained, how the school might be different in five years, and what supporters in the community of frontier schools must do if they want the school to remain sustained and viable to meet the needs of students.

Although survey results provided much data to inform work of the Montana Small Schools Alliance, focus group results added critical information not previously collected in past years by MSSA. Survey results clearly revealed that agriculture is the most prevalent type of economic base in over four-fifths $(85.4 \%)$ of respondents' districts, followed by 'mixed economies.' Some mixed economies also included agriculture. This means that almost $90 \%$ of frontier school districts exist primarily because the parents work in the agriculture sector of the economy, producing important products such as beef, pork and wheat. One focus group participant described the school as closely associated with the culture of agriculture, as a way of life that was much different than life in town, noting: "It's a culture. That's how you'd say it, a heritage. Yeah, that's a good way of saying it." Another participant describing the frontier school noted.

I just think they're definitely a necessity. I guess that's how I would describe our [frontier] school. It's a good place. We need to have a good foundation for our kids, as far as keeping the family closer to home, because once we have to shuttle the kids to town it's a whole new world out there. And it puts a greater stress, I think, on the family unit.

This participant lived 38 miles from town, on an unpaved road, and explained that if the children had to go to the "town school" it would necessitate that the mother and children live in town during the week 
while the father lived and worked on the ranch. Such a living situation would cause additional stress on the family unit: "It's a hardship financially. It's a hardship emotionally. It's a great sacrifice."

Focus group participants offered numerous examples of how they, other parents/families, and community members value their schools. One participant noted.

It's a whole different life when they have to go to town. My kids would be gone, you know, I'd have to leave by 5:30 am, maybe 6 am if the roads were good to get them to the bus so they could ride 15 or 16 more miles. We would have to drive them 25 miles on a dirt road to get them to the bus, or move to town.

Another participant commented on the impact of school closure on the way of life, If [the school] closes down you lose all the good people that are teaching there, and more than likely everything will follow. Everything will close because the families will leave, so then there's nobody to support our store and the restaurant and businesses that are in town, which aren't very many, but to us they are important. If we lose the school, it's 35 miles to [the next school].... That is not an option. It would be a 50-mile trip for her [the wife]. It would split the family. The husband would have to stay home and run the ranch, and she would have to go to town [with the children].

Many focus group participants also saw the impact of having a school on the community, for example, when hiring employees for ranches and local businesses, the presence of a school was an important factor for potential applicants or sons or daughters considering returning to the community. On sustaining the school, one participant remarked.

I think a lot of people are very supportive of having a school in the rural area because if they have a family that comes in to the area or a son that comes back with a family, they want to be able to have the school there for their children.

Some participants wanted their children to go to a college and university to learn about modern agricultural practices as preparation for coming back to work in the area or to take over the ranching operation and provided numerous examples of how their children or children of others who attended the small school now live in the community and work as nurses, run their own business (e.g., outfitting) or are ranchers. One participant explained.

Not all children want to leave the area.

They didn't leave. They love this life, they want to be in it, and they want to raise their kids in it. I think that comes from enjoying the school that they grew up in and the type of lifestyle that they were involved in. It is appealing to the children of our children. Not all of them, but a lot of them will come back and be the next generation of us.

As one participant explained the importance of connecting children to their community roots, many other participants nodded their heads in agreement:

In the country the small schools are necessity because of the desire to keep the children involved in ranching, in agribusiness. Most of the small towns are agricultural based areas. Parents desire to keep the kids involved and teach them along the way.... So by sending them to town, from kindergarten all the way up they've missed out on learning about ranching. They learn to work. And they're important to the community.

All participants agreed that schools are part of the communities, noting that "If we lose them, then we lose our communities." They strongly emphasized the importance of schools in sustaining the rural ranching life-style.

While farming and ranching do not require the number of Americans to be involved as in past decades, they do require some Americans who want to work the land and be part of the rural lifestyle associated with ranching.

Removing the frontier schools would threaten the existence of agricultural production in Montana.

\section{Discussion}

Small rural schools on the Montana "frontier" have numerous challenges, as do most schools in America. But the challenges of frontier schools in Montana appear unique to the agricultural way of life that has prevailed since establishment of the West. This finding is consistent with a national study of K12 unit schools (i.e., all grades in one school) conducted more than a decade ago by Howley \& Harmon (2000b). Their data revealed that K-12 unit schools were usually located in agricultural regions 
where socioeconomic status was lower than the national average. Most K-12 unit schools were remote from resources such as hospitals, interstate highways, and cities. Howley and Harmon also found that community attitudes toward single-school districts were moderately and positively related to the sustainability of the school. Single school districts, compared to multi-school districts with a K-12 unit school, used cooperative strategies for maximizing resources, such as joining a regional educational service agency or cooperating with other districts. In Montana, a substantial percentage of the "frontier schools" join the Montana Small Schools Alliance for access to educational support services and networking. In 2005, a regional education service agency network began evolving in the state.

Arguably, elementary schools on the Montana frontier might be characterized as a modern version of the one-room schoolhouse of years gone by. Although many Montana elementary schools on the frontier have no cafeteria, lay citizens in focus group sessions did not see this as a disadvantage to the school or an issue that threatens its sustainability. Perhaps the parents of these children perceive packing a lunch as a parent's responsibility, rather than the school having to provide a "free lunch." Many ranching families have wealth as property owners but small incomes, and thus would have children that qualify as eligible for the federal free and reduced price lunch program. One cannot conclude that these "impoverished" children come from homes without the food necessary for bringing a nutritious lunch to school. It is likely also that packing a lunch when a student must be away from home for the day is an accepted way of life on the frontier. Additional research is necessary to investigate this issue, particularly for frontier schools catering to substantial numbers of children from nonranching families, or single parent families.

Declining populations and subsequent loss of school revenue is the issue that most threatens sustaining the small frontier school and its community. Teachers and administrators typically express concerns about budget issues, curriculum offerings, managing multi-grade classrooms, inappropriate state and federal mandates, recruiting and retaining teachers, and isolation from colleagues. While these are critical schooling issues to educators, lay citizens, on the other hand, are more likely to see the school as a vital necessity for maintaining a way of life associated with agriculture and related enterprises. Although recognizing that children need a quality education that prepares them for living in a global world, lay citizens clearly expect the school to support the aspirations and values of living and working in agricultural or other enterprises on the frontier. Lay citizens in the focus groups also understood how agricultural and other enterprises are changing to accommodate global competition, technology innovations, markets for products, and other issues.

A vast majority of these lay citizens also believes that most Americans have little understanding of what it means to live and work in a ranching culture and community. In their view, most policymakers and funders of public education seem to lack an understanding of how very essential schools are to communities, families, and to the ways of life in isolated rural areas. This belief appears consistent with many reports describing the reasons parents and community residents give when combating school closure or consolidation (Beeson, 2002; Celis, 2002; Walker, 2010). For example, Howley \& Harmon (2000b) described a small high school in Tennessee that survived and flourished because of community commitment based on values of family, hard work, and caring for others; community expectations that students may leave to discover a "vocation" elsewhere, but will return with new skills to benefit the community; and a willingness among wealthy residents and businesses to provide supplemental funding. In sustaining the high school, the community articulated a view of the outside world that reflected respect for local perspectives and put local purposes before global ones.

The viewpoints of Montana citizens who participated in the focus groups in this study resemble those presented in other research (Post \& Stambach, 1999) that highlights a deep and enduring social tension between the centralizing movements of governing bodies, particularly to reduce the costs of providing a public education, and the decentralizing interests of local communities that seek to retain and to define their own identity. Moreover, viewpoints of focus group participants resemble long-held arguments that isolation in rural areas creates the necessity of small schools (Bass, 1988; Bohrson \& Gann, 1963; Gjelten \& Nachtigal, 1979) and the need to provide public education. In essence, focus group participants argue that residents throughout the state and across the nation enjoy the products that come from isolated rural areas of Montana. Thus, policymakers should support public education as a necessary basic service for citizens who produce the products and choose the associated way of life in isolated rural areas.

The divisive debates and the effects of school consolidation or closure in rural communities are captured in books like There Goes the Neighborhood: Rural School Consolidation at the Grass Roots in Early Twentieth-Century Iowa (Reynolds, 1999) and DeYoung's (1995) The Life and Death of a Rural 
American High School: Farewell Little Kanawha. Such struggles hover on the horizon for frontier schools in Montana and perhaps elsewhere, unless local, state and national leaders unite in a vision to sustain public schools that serve a predominately agricultural and isolated lifestyle that is virtually unknown, and perhaps undesired, as a way of living and working by most Americans today.

Results of this study bring to light issues of the one-room school and its historical struggle to exist as a center venue for community life in rural America (Zimmerman, 2009). As Zimmerman writes in Small Wonder: The Little Red Schoolhouse in History and Memory, the one-room school was "neither as rundown as critics claimed nor as bucolic as defenders imagined" (Cited in Kauffman, 2009). For many parents and citizens, the struggle to keep the one-room school was about defending principles of local autonomy and human-scale democracy.

Lay citizens who participated in the focus groups in this study believe they must begin networking with leaders inside and outside of their communities to collect and share factual information on the benefits of a frontier school to its community. In their view, working and living on the frontier is not for most people, but state and federal policy decisions should support public education that seeks to serve families and communities in isolated rural areas.

\section{Conclusion}

Both educators and lay citizens in this study provide numerous examples of how the small schools, immersed in a culture seldom experienced by most Americans, benefit them and students. The challenges of declining student populations, funding limitations, and other issues are accelerating, with negative consequences on schools and communities. Sustaining a public school in this unique place of the American landscape will require collaboration and change by those who live inside and outside frontier areas like Montana. Thanks to funding provided by the Oro Y Plata Foundation, this research will help guide work of the Montana Small Schools Alliance in supporting the frontier schools of Montana, as well as inform leaders in other rural communities that embrace public education as a cornerstone of their future prosperity.

\section{Suggestions for Future Research}

From this study, the researchers learned that educators and lay citizens on the Montana frontier are well aware of the modern demands on them to provide a quality public education for all students. Schools obviously play a critical role in the future prosperity of individual students as well as their communities. Schools are expected to support the culture and way of life associated with living on the frontier, while also educating students for a productive future regardless of where they choose to live.

Educating students in frontier areas seems to demand understanding a context that honors practicality for making a living and reinforces the unique value of culture in student and community development. Educators and other residents live on the frontier because they identify with and want to contribute to this unique way of life, but increasingly they face challenges that attract little attention from those who could help provide meaningful solutions.

We offer a list of 12 research questions that may help address some critical issues associated with offering public education in rural communities of states with "frontier" areas. Frontier schools are an important segment of public education that deserve the urgent attention of policymakers, researchers, technical assistance providers, and private foundations.

1. What collaborative approaches among communities, educators, governmental agencies, and entities in the private sector offer the most promise for addressing population loss in frontier areas? 2. What joint policy and funding strategies should be targeted between the US Department of Education and the US Department of Agriculture to support educating students in frontier areas?

3. What current and evolving learning technologies have applications for increasing curriculum offerings, student learning, and teacher development in frontier areas?

4. What are the most critical professional development needs of teachers who work in frontier schools for addressing meaningful problems of practice, particularly teachers who serve dual instructional and administrative roles?

5. What strategies offer the most promise in addressing teacher recruitment and retention issues of schools districts in frontier areas?

6. How could community leaders, lay citizens, and educators collect and disseminate accurate information to effectively reveal the essential role of schools to community viability and prosperity in frontier areas?

7. What state and federal education policy and funding practices are necessary to support educating students in frontier areas that complement local control of "public" schools, including virtual schools and public charter schools?

8. How does academic performance of students in frontier schools compare to that of students in other rural, urban and suburban schools? 
9. If this study was replicated in other western states would the challenges and sustainability practices of those frontier schools be similar or different from the Montana study?

10. What are the educational and career aspirations of high school seniors in frontier areas?

\section{References}

Allen, D. M., \& Sloan, J. E. (2005).Adequacy-based funding for small, isolated schools: An approach for Maine. Paper presented at the Annual Meeting of the New England Educational Research Organization, Northampton, Massachusetts, April 2005. (ERIC Document Reproduction Service No. ED509454)

Alliance for Excellent Education. (2010). Current challenges and opportunities in preparing rural high school students for success in college and careers: What federal policymakers need to know. Washington, DC: Author. Retrieved from http://www.all4ed.org/files/RuralHSReportChall engesOpps.pdf

Bass, G. R. (1988). Financing for small schools: A study. Rural Educator, 9(2), 9-14.

Beaulieu, L., \& Gibbs, R. (2005). The role of education: Promoting the economic and social vitality of rural America. Mississippi State, MS: Southern Rural Development Center.

Beeson, E. (Ed.). (2002). Rural policy matters: A newsletter of rural school \& community action. Rural Policy Matters, 4(4), 1-12.

Bohrson, R. G., \& Gann, E. L. (1963). Programs for those rural schools which are necessarily existent. Washington, DC: United States Department of Health, Education \& Welfare, Office of Education, National Committee for Children and Youth. (ERIC Document Reproduction Service No. ED012644)

Broton, K., Mueller, D., Schultz, J. L., \& Gaona, M. (April, 2009). Strategies for rural Minnesota school districts: A literature review. St. Paul, MN: Wilder Research.

Brown, D.L., \& Swanson, L.E. (2003). Challenges for rural America in the twenty-first century. University Park, PA: The Pennsylvania State University Press.

Celis, W. (2002).Battle rock: The struggle over a one-room school in America's vanishing west. New York: Public Affairs. (ERIC Documents Reproduction Service No. ED 470471)

Chance, E., \& Cummins, C. (1998, Winter). School/community survival: Successful strategies used in rural school district consolidations. Rural Educator, 20(2), 1-7.
11. What knowledge, skills, dispositions and life experiences best describe an effective teacher in frontier schools?

12. How can teacher education programs best prepare teachers for success in frontier schools?

DeYoung, A. J. (1987). The status of American rural educational research: An integrated review and commentary. Review of Educational Research, 57(2), 123-48.

DeYoung, A. J. (Ed.). (1991). Rural education issues and practice. New York: Garland.

DeYoung, A. J. (1995). The life and death of a rural American high school: Farewell little Kanawha. New York: Garland.

Fuller, W. (1982). The old country school: The story of rural education in the Middle West.Chicago: University of Chicago Press.

Gaither, M. (2003). American educational history revisited. New York: Teachers College Press.

Gjelten, T. (1982). Staples, Minnesota: Improving the schools to save the town. In P. Nachtigal (Ed.), Rural education: In search of a better way (pp. 247-265). Boulder, CO: Westview Press.

Gjelten, T., \& Nachtigal, P. (1979). Improving rural education: Past efforts, some ideas for the future. Denver, CO: Educational Commission of the States; Washington, DC: Department of Health, Education, and Welfare, Office of Education, Bureau of Elementary and Secondary Education; Washington, DC: Department of Agriculture; Washington, DC: National Institute of Education, Office of the Assistant Secretary of Education. (ERIC Document Reproduction Services No. ED 172979)

Harmon, H.L. (2003). Rural education. In J. W. Guthrie (Ed.), Encyclopedia of education ( $2^{\text {nd }}$ ed., pp. 2083-2090). NY: Macmillan Reference.

Harmon, H. L., \& Schafft, K. A. ( 2009). Rural school leadership for collaborative community development. The Rural Educator, 30(3), 4-9.

Howley, C. B., \& Harmon, H. L. (2000a). K-12 unit schooling in rural America: A first description. The Rural Educator, 22(1), 10-18

Howley, C. B., \& Harmon, H. L. (2000b).Community as tacit curriculum: A case study of Oneida high school, Oneida, Tennessee. In C.B. Howley \& H. L. Harmon (Eds.), Small high school that flourish: Rural context, case studies, and resources (pp. 61-88). Charleston, WV: AEL,.

Howley, C., Johnson, J., \& Petrie, J. (2011). Consolidation of schools and districts: What the research says and what it means. Boulder, CO: National Education Policy Center. 
Kauffman, B. (June 30, 2009).In one room, many advantages. Wall Street Journal, p. 13A. Retrieved May 31, 2011, from http://online.wsj.com/article/SB12463195396557 0969.html

Kliewer, L. (March, 2001). Small, rural schools face uncertain future due to predictions of declining enrollment. Firstline Midwest, 3(3), 4. Lombard, IL: Midwestern Office of the Council of State Governments. Retrieved May 9, 2011 from http://www.csg.org/knowledgecenter/docs/flmw0103.pdf

Lyson, T. (2002, Winter). What does a school mean to a community? Assessing the social and economic benefits of schools to rural villages in New York. Journal of Research in Rural Education, 17(3), 131-137.

McCulloch, L. (2008). Directory of Montana Schools, 2008-2009. Helena, MT: Office of Public Instruction.

Miller, B. (1993, Fall). Rural distress and survival: The schools and the importance of "community." Journal of Research in Rural Education, 9(2), 84-103.

Montana Department of Commerce.(2008, July).Data maps. Helena, MT: Census and Economic Information Center, Montana Department of Commerce.

National Center for Frontier Communities. (2007). Developing the consensus definition. Ojo Sarco, NM: National Center for Frontier Communities.

Post, D., \& Stambach, A. (1999). District consolidation and school closure: E Pluribus Unum? Journal of Research in Rural Education, 15(2), 106-117.

Powers, A. (2009, January 22). Weak economy threatens rural schools. Los Angeles Times. Retrieved August 3, 2011, from http://articles.latimes.com/2009/jan/22/nation/narural-school-closures22

Provasnik, S., Kewal R.A., Coleman, M.M., Gilbertson, L., Herring, W., \& Xie, Q. (2007). Status of Education in Rural America (NCES 2007-040). Washington, DC:

National Center for Education Statistics, Institute of Education Sciences, U.S. Department of Education. (2002). Rural school achievement program to the elementary and secondary education act. (No Child Left Behind Act of 2001). Washington, DC: United States Congress.

Reynolds, D. R. (1999). There goes the neighborhood: Rural school consolidation at the grass roots in early twentieth-century Iowa. Iowa City, IA: University of Iowa Press.

Ross, T. (2011, August 3). Edu. official: Demographics challenge Neb. Schools. TimesUnion.Com. Retrieved August 4, 2011 from http://www.timesunion.com/news/article/Eduofficial-Demographics-challenge-Neb-schools1710721.php\#ixzz1U42TJFWY

Scafft, K. A., \& Harmon, H. L. (2010). Schools and community development. In J. W. Robinson, Jr., \& G. P. Green (Eds.). Introduction to community development: Theory, practice, and service learning (pp. 245-259). Thousand Oaks, CA: Sage.

Stephens, E. R. (1998). Expanding the vision: New roles for educational service agencies in rural school district improvement. Charleston, WV: AEL(now Edvantia, Inc.), The Rural Center.

The Associated Press (March 13, 2009). Economic crisis threatens small, rural schools. Retrieved May 9, 2011, from http://www.msnbc.msn.com/id/29681556/ns/us_ news-education/t/economic-crisis-threatenssmall-rural-schools/

U.S. Department of Education, (2002). Subpart 1 Small rural school achievement programeligibility: Reauthorization of the elementary and secondary education act Washington, DC: U.S. Congress.

Walker, M. (2010). Choice, cost and community: The hidden complexities of the rural primary school market. Educational Management Administration \& Leadership, 38(6), 712-727.

Williams, J., Nierengarten, G., Munson, B., Riordan, K., \& Corbett, D. (2009). Learning communities in transition: The voice of rural administrators. In A Region Apart: Rural Education in Minnesota. Mankato, MN: Center for Rural Policy Development.

Zimmerman, J. (2009). Small wonder: The little red schoolhouse in history and memory. Cambridge, MA: Yale University Press.

Dr. Claudette Morton served as the Executive Director of the Montana Small Schools Alliance for more than 14 years, retiring in June 2010. Now an independent consultant, Dr. Morton previously worked as a college administrator, staff member of the Montana state education agency, and administrator for the Montana Board of Public Education.

Dr. Hobart Harmon is an independent consultant with specialization in educational planning, research and evaluation. Dr. Harmon provides planning and external evaluation services for grant-funded school improvement projects across the U.S. and conducts research on issues important to rural school and communities. 